\title{
COMPARISON BETWEEN THE MICROBIOLOGICAL STATUS OF RAW AND PASTEURIZED MILK YOGHURT
}

\author{
O.A. SADEK; MANL M. AMIN and M.F. HUSSEIN \\ Animal Health Research Institute - Assiut Regional Lab.
}

Email: Mahmoudfarghaly_1970@yahoo.com.

\section{ABSTRACT}

Received at: $24 / 6 / 2014$

This investigation was run to compare the microbiological quality between raw and pasteurized milk yoghurt. A total of 70 raw and pasteurized milk yoghurt samples (35 samples of each) were collected from small dairies and supermarkets in Assiut City, Egypt. All samples were investigated to determine the Enterococci, yeasts and molds, Staphylococcus aureus, coliforms, faecal coliforms and E. coli count. Also, for detection of anaerobes. In raw milk yoghurt samples the incidences of Enterococci, yeasts and molds, coliforms, faecal coliforms and E. coli were 40, 82.9, $62.9,57.1$ and $54.3 \%$, respectively; while, for pasteurized milk yoghurt samples, the incidences were 22.9, 77.1, 2.9, 2.9 and 2.9\%, respectively. On the other hand, Staphylococcus aureus and anaerobes could not be detected in this study. The microbiological results in this study were compared with the limits of Egyptian Organization Standards.

Key words: Microbiology, Raw, Pasteurized, Milk yoghurt.

\section{INTRODUCTION}

Human consumption of fermented milk dates from the beginning of civilization, once residues of these products were found in pottery fragments from Neolithic, Bronze and Iron Ages settlements in Britain (McKinley, 2005). It is accepted that, the initial consumption of fermented or cultured milk products, such as yoghurt, butter and cheese, occurred around the time as they were recognized as effective means of prolonging the shelf-life of milk (Ross et al., 2002).

Yoghurt is generally known as cultured milk, as it is derived from the action of bacteria (Streptococcus thermophilus and Lactobacillus delbrueckii spp. Bulgaricus) on all or part of the lactose to produce lactic acid, carbon dioxide, acetic acid, diacetyl, acetaldehyde and several other components that give the product its characteristic fresh taste (Tamine and Robinson, 2004). The increase in the per capita annual consumption of yoghurt in the majority of the countries has been attributed to both the everincreasing availability of fruit or flavored yoghurt, and to the diversity of presentations of the product (Tamime and Robinson, 2007).

Likewise, yogurt has been known for its nutraceutical, therapeutic, and probiotic effects such as digestion enhancement, immune system boosting, anti-carcinogenic activity and reduction of serum cholesterol (Penna et al., 2007). The yoghurt production is quite simple, and the rising consumption of this product has led to the development of automated and sophisticated equipment for the industrial processing. Despite the practicability, the current processing equipments must provide proper quality and safety (Salinas, 1986).

Poor micobiological quality of milk, contamination during production, unsuitable storage, lack of personal hygiene and premises will affect the microbiological quality of yoghurt and its shelf life. Since, milk and milk products are good vehicles for both beneficial and harmful microorganisms, some of which may have health and subsequent financial consequences to the consumer, it is important to independently monitor quality. Although many studies have been done by numerous researchers throughout the world to determine the microbiological status of pasteurized milk yoghurt, but there is paucity of information and there are no sufficient works in Egypt about raw milk yoghurt. Therefore, this work aimed to compare the microbiological status of raw and pasteurized milk yoghurt.

\section{MATERIALS and METHODS}

A total of 70 random yoghurt samples comprising (35 raw milk yoghurt samples produced by small dairies in Assiut city and 35 pasteurized milk yoghurt samples produced by modern dairies) were collected 
from small dairies and supermarkets in Assiut city. The samples were collected in clean plastic bags as marketed to the consumers and transported, as soon as, possible to the laboratory were subjected the following microbiological examination:-

Total coliform, faecal coliform and E. coli counts (MPN) according to FAO (1992).

Enterococci count according to Deibel and Hartman (1982).

Staphylococcus aureus count according to A.O.A.C. (2000)
Yeasts and molds counts according to Harrigan and MeCance (1976)

Detection of anaerobes by Stormy fermentation test according to Cruickshank et al. (1969).

Statistical analysis:

The resulting data were analyzed using SPSS (2007) for Windows (SPSS, version 16, Inc., Chicago, IL). Chi-square test and t-test analysis were performed, differences were considered significant at values of $\mathrm{p}<0.05$.

\section{RESULTS}

Table 1: Statistical analytical results of microbiological examination of raw and pasteurized milk yoghurt samples.

\begin{tabular}{|c|c|c|c|c|c|c|c|c|c|c|}
\hline \multirow{3}{*}{$\begin{array}{c}\text { Microbial } \\
\text { Examination }\end{array}$} & \multicolumn{5}{|c|}{ Results of raw milk yoghurt counts (cfu/g) } & \multicolumn{5}{|c|}{ Results of pasteurized milk yoghurt counts (cfu/g) } \\
\hline & \multicolumn{2}{|c|}{$\begin{array}{l}\text { Positive } \\
\text { Samples }\end{array}$} & \multirow{2}{*}{ Min. } & \multirow{2}{*}{ Max. } & \multirow{2}{*}{ Average } & \multicolumn{2}{|c|}{$\begin{array}{l}\text { Positive } \\
\text { Samples }\end{array}$} & \multirow{2}{*}{ Min. } & \multirow{2}{*}{ Max. } & \multirow{2}{*}{ Average } \\
\hline & No./35 & $\%$ & & & & No./35 & $\%$ & & & \\
\hline Enterococci & 14 & 40 & $1.00 \times 10^{2}$ & $5.50 \times 10^{4}$ & $9.26 \times 10^{3^{*}}$ & 8 & 22.9 & $1.00 \times 10^{2}$ & $5.70 \times 10^{4}$ & $1.71 \times 10^{4^{*}}$ \\
\hline $\begin{array}{l}\text { Staph. } \\
\text { aureus }\end{array}$ & 0 & 0 & 0 & 0 & 0 & 0 & 0 & 0 & 0 & 0 \\
\hline Anaerobes & 0 & 0 & 0 & 0 & 0 & 0 & 0 & 0 & 0 & 0 \\
\hline $\begin{array}{l}\text { Yeasts \& } \\
\text { Molds }\end{array}$ & 29 & 82.9 & $1.00 \times 10^{2}$ & $1.16 \times 10^{5}$ & $1.60 \times 10^{4 * *}$ & 27 & 77.1 & $2.00 \times 10^{2}$ & $3.40 \times 10^{3}$ & $6.37 \times 10^{2 * *}$ \\
\hline
\end{tabular}

* means no significance difference $(\mathrm{F}=0.282$ and $\mathrm{P}>0.05)$.

** means high significance difference $(\mathrm{F}=25.440$ and $\mathrm{P}<0.01)$.

Table 2: Incidence of coliforms, faecal coliforms and E. coli recovered from yoghurt samples using MPN/g technique.

\begin{tabular}{|c|c|c|c|c|c|c|}
\hline \multirow{2}{*}{$\begin{array}{l}\text { Types of yoghurt } \\
\text { samples }\end{array}$} & \multicolumn{2}{|c|}{$\begin{array}{l}\text { Positive samples recovered } \\
\text { coliforms }\end{array}$} & \multicolumn{2}{|c|}{$\begin{array}{l}\text { Positive samples recovered } \\
\text { faecal coliforms }\end{array}$} & \multicolumn{2}{|c|}{$\begin{array}{l}\text { Positive samples } \\
\text { recovered } E \text {. coli }\end{array}$} \\
\hline & No./35 & $\%$ & No./35 & $\%$ & No./35 & $\%$ \\
\hline Raw milk yoghurt & 22 & $62.9^{* *}$ & 20 & 57.1 & 19 & 54.3 \\
\hline $\begin{array}{l}\text { Pasteurized milk } \\
\text { yoghurt }\end{array}$ & 1 & $2.9^{* *}$ & 1 & 2.9 & 1 & 2.9 \\
\hline
\end{tabular}

** means high significance difference $\left(\chi^{2}=28.55\right.$ and $\left.\mathrm{P}<0.01\right)$. 
Table 3: Frequency distribution of positive yoghurt samples based on coliforms, faecal coliforms and $E$. coli counts using MPN/g technique.

\begin{tabular}{|c|c|c|c|c|c|c|c|c|c|c|c|c|}
\hline \multirow{3}{*}{ Range } & \multicolumn{6}{|c|}{ Raw milk yoghurt samples (No./35). } & \multicolumn{6}{|c|}{ Pasteurized milk yoghurt samples (No./35). } \\
\hline & \multicolumn{2}{|c|}{ Coliforms } & \multicolumn{2}{|c|}{$\begin{array}{c}\text { Faecal } \\
\text { coliforms }\end{array}$} & \multicolumn{2}{|c|}{ E. coli } & \multicolumn{2}{|c|}{ Coliforms } & \multicolumn{2}{|c|}{$\begin{array}{c}\text { Faecal } \\
\text { coliforms }\end{array}$} & \multicolumn{2}{|c|}{ E. coli } \\
\hline & No. & $\%$ & No. & $\%$ & No. & $\%$ & No. & $\%$ & No. & $\%$ & No. & $\%$ \\
\hline$<3^{*}$ & 13 & 37.1 & 15 & 42.9 & 16 & 45.7 & 34 & 97.1 & 34 & 97.1 & 34 & 97.1 \\
\hline $3-<10$ & 9 & 25.7 & 7 & 20 & 6 & 17.1 & 0 & 0 & 0 & 0 & 0 & 0 \\
\hline $10-<10^{2}$ & 2 & 5.7 & 4 & 11.4 & 4 & 11.4 & 1 & 2.9 & 1 & 2.9 & 1 & 2.9 \\
\hline $10^{2}-<10^{3}$ & 5 & 14.3 & 3 & 8.6 & 3 & 8.6 & 0 & 0 & 0 & 0 & 0 & 0 \\
\hline$\geq 10^{3}$ & 6 & 17.1 & 6 & 17.1 & 6 & 17.1 & 0 & 0 & 0 & 0 & 0 & 0 \\
\hline Total & 35 & 100 & 35 & 100 & 35 & 100 & 35 & 100 & 35 & 100 & 35 & 100 \\
\hline
\end{tabular}

$<3 *$ means negative MPN tubes

Table 4: Summarized results of microbiological examination of raw and pasteurized milk yoghurt samples sold in Assiut city compared with the Egyptian Standards (E.O.S.Q.C., 2005).

\begin{tabular}{cccccccccc}
\hline & & \multicolumn{3}{c}{ Raw milk yoghurt samples } & \multicolumn{2}{c}{ Pasteurized milk yoghurt samples } \\
\cline { 3 - 9 } Organisms & Standards & Unacceptable & Acceptable & Unacceptable & Acceptable \\
\cline { 3 - 9 } & & No./35 & $\%$ & No./35 & $\%$ & No./35 & $\%$ & No./35 & $\%$ \\
\hline Enterococci & Free & 14 & 40 & 21 & 60 & 8 & 22.9 & 27 & 77.1 \\
\hline Staph. aureus & Free & 0 & 0 & 35 & 100 & 0 & 0 & 35 & 100 \\
\hline Coliforms & Free & 22 & 62.9 & 13 & 37.1 & 1 & 2.9 & 34 & 97.1 \\
\hline $\begin{array}{c}\text { E. coli } \\
\text { Yeasts \& }\end{array}$ & Free & 19 & 54.3 & 16 & 45.7 & 1 & 2.9 & 34 & 97.1 \\
\hline Molds & Not more & 29 & 82.9 & 6 & 17.1 & 27 & 77.1 & 8 & 22.9 \\
\hline
\end{tabular}

\section{DISCUSSION}

The illustrated results in Table 1 revealed that, $40 \%$ of the examined raw milk yoghurt samples were contaminated with Enterococci with a count/g ranged from $1.00 \times 10^{2}$ to $5.50 \times 10^{4}$ with an average count of $9.26 \times 10^{3} / \mathrm{g}$. Lower result $(28 \%)$ was detected by Sayed (2012), while, higher results (75, 68 and 58\%) were reported by Ahmed and El-Bassiony (1978), ElBessery (2001) and El-Malt et al. (2013), respectively. The incidence of Enterococci in pasteurized milk yoghurt samples was $22.9 \%$ with count/g ranged from $1.00 \times 10^{2}$ to $5.70 \times 10^{4}$ and the average count was $1.71 \times 10^{4} / \mathrm{g}$ (Table 1 ). Lower result $(8 \%)$ was estimated by Sireli and Ozdemir (1998). 
The using of statistical analysis between the results of Enterococci count/g in raw and pasteurized milk yoghurt by using SPSS program, the t-test showed that, there was no significance difference between the counts/g in both types of yoghurt $(\mathrm{F}=0.282$ and $\mathrm{P}>$ $0.05)$. Furthermore, the relatively higher average of Enterococci count in pasteurized milk yoghurt than in raw milk yoghurt may be due to the lower acidity of pasteurized milk yoghurt which favored Enterococci growth than raw milk yoghurt acidity which hamper of some Enterococci growth.

The high incidence of Enterococci in this study may be due to the fact that Enterococci are comparatively heat resistant, salt tolerant, grow at wide range of temperatures, low $\mathrm{pH}$ and more resistant to drying, detergents and disinfectants (ICMSF, 1982). Additionally, some of them may help in assessment of the hygienic standard in dairy farms and factories of fermented milks as they are sometimes causing food poisoning (Sinigaglia et al., 1997 and Roushdy et al., 1998). Likewise, they considered a useful indicators of possible presence of enteric pathogens (Rao et al., 1986).

According to the limits proposed by the E.O.S.Q.C. (2005), 40 and $22.9 \%$ of the examined raw and pasteurized milk yoghurt samples, respectively, failed to comply with the limits (Table 4) due to the presence of Enterococci. This result indicated the negligible sanitary control measures during production and handling of the products.

The results listed in Table 1 revealed that, yeasts and molds were found in $82.9 \%$ of the examined raw milk yoghurt samples with count/g ranged from $1.00 \times 10^{2}$ to $1.16 \times 10^{5}$ with an average count of $1.60 \times 10^{4} / \mathrm{g}$. Higher result $94 \%$ was estimated by El-Malt et al. (2013). Concerning pasteurized milk yoghurt, 77.1\% of the samples were contaminated by yeasts and molds with count/g ranged from $2.00 \times 10^{2}$ to $3.40 \mathrm{X}$ $10^{3}$ and an average count of $6.37 \times 10^{2} / \mathrm{g}$ (Table 1 ). Lower incidences (50 and 40\%) were obtained by ElDiasty and El-Kaseh (2007) and El-Malt et al. (2013), respectively. While, higher count $\left(1.4 \times 10^{5} / \mathrm{g}\right)$ was mentioned by Isam et al. (2011). High significance difference in yeasts and molds counts/g between raw and pasteurized milk yoghurt in this study by using t-test was found $(F=25.440$ and $P<0.01)$. It worth to mention that, the relatively higher average of yeasts and molds count in raw milk yoghurt than in pasteurized milk yoghurt may be due to the higher acidity of raw milk yoghurt than in pasteurized milk yoghurt which favoured the yeasts and molds growth and flourishing.

The presence of yeasts and molds in a relatively high counts in examined yoghurt samples may indicate inefficient pre-heating process during manufacturing, using unsatisfactory sterilized plastic cups in packing or inefficient chilling on storage (Saudi et al., 1989). Moreover, yoghurt by nature is a high acidic product, therefore, it may be considered as a highly selective environment favouring the growth of yeasts and molds as spoilage microorganisms and utilize some of the acid and produce a corresponding decrease in the acidity, which may favour the growth of putrefactive bacteria, as well as, their presence in yoghurt is being indicative of poor sanitary practices (Oyeleke, 2009 and El-Malt et al., 2013). From Table 4, one can easily concluded that, 82.9 and $77.1 \%$ of raw and pasteurized milk yoghurt samples, respectively, failed to comply with the limits of the Egyptian Standards due to the presence of yeasts and molds which indicated the poorer sanitary practices during yoghurt production.

Concerning Staphylococcus aureus, the organism could not be detected in this study in raw and pasteurized milk yoghurt samples (Tables 1). Similar results were obtained by Rodriguez et al. (1990); ElBessery (2001); Isam et al. (2011); Sasidharan et al. (2011) and Rahimi (2013) as the authors failed to detect Staph. aureus in yoghurt samples. From Table 4 , it is worth to mention that, $100 \%$ of the examined raw and pasteurized milk yoghurt samples were comply with the limits of Egyptian Standards for the absence of Staph. aureus in yoghurt samples. The failure of Staph. aureus detection in this study may be due to $\mathrm{pH}$ of yoghurt, lactic acid and inhibitory substances produced by yoghurt culture which reduce or inhibit Staph. aureus growth in yoghurt (Pazakova et al., 1997). Moreover, such organisms were inhibited after few days during storage of fermented product (Estrada et al., 1999).

The results tabulated in Table 2 revealed that, $62.9 \%$ of raw milk yoghurt samples recovered coliforms. The highest frequency distribution of coliforms was $(25.7 \%)$ and laid in the range of $3-<10 \mathrm{cfu} / \mathrm{g}$ (Table $3)$. Lower result $(22 \%)$ was estimated by Sayed (2012). While, higher results (70, 70 and 82\%) were reported by Ahmed and El-Bassiony (1978), ElBessery (2001) and Al-Hawary (2005), respectively. Concerning pasteurized milk yoghurt, $2.9 \%$ of samples were positive for coliforms (Table 2) and with frequency distribution of $2.9 \%$ and laid in the range of $10-<10^{2} \mathrm{cfu} / \mathrm{g}$ (Table 3 ). Higher results (10 and $40 \%$ ) were estimated by El-Diasty and El-Kaseh (2007) and Yasen et al. (2011), respectively. Furthermore, high significance difference between the results of coliforms in raw milk yoghurt and pasteurized milk yoghurt by using Chi-square was found in this study $\left(\chi^{2}=28.55\right.$ and $\left.\mathrm{P}<0.01\right)$.

According to the limits proposed by Egyptian Standards based on presence of coliforms, 62.9 and $2.9 \%$ of raw milk yoghurt and pasteurized milk yoghurt samples, respectively, failed to comply with the standards (Table 4). Furthermore, presence of 
coliforms in raw milk yoghurt revealed that, bad hygienic measures during production, use of poor quality raw milk and insufficient preheating process. Whereas, presence of coliforms in pasteurized milk samples indicated that, post pasteurization contamination during yoghurt production. Moreover, the rate of contamination in raw milk yoghurt processing with coliforms was higher than in pasteurized milk yoghurt processing because of the differences in the practices between different manufacturers (Dardashti et al., 2001). Coliforms are routinely used as indicator to the quality of the milk and milk products and some members of coliforms are responsible for the development of objectionable taints in milk and its products rendering them of inferior quality or even unmarketable.

Yoghurt should be free from faecal coliforms, but the result in Table 2 showed that, $57.1 \%$ of raw milk yoghurt samples had faecal coliforms with highest frequency distribution of $20 \%$ and laid in the range of $3-<10 \mathrm{cfu} / \mathrm{g}$ (Table 3). Lower result $2 \%$ was reported by Sayed (2012), while, higher result was reported by El-Malt et al. (2013) as the authors recorded that (35 samples out of 50 samples) were contaminated by faecal coliforms. Concerning pasteurized milk yoghurt, $2.9 \%$ of samples reveled faecal coliforms (Table 2) and the highest frequency distribution was $2.9 \%$ and laid in the range of $10-<10^{2} \mathrm{cfu} / \mathrm{g}$ (Table 3). Higher result was reported by El-Malt et al. (2013) as the workers recorded that 17 samples out of 50 samples were contaminated by faecal coliforms. Presence of faecal coliforms in the examined samples considered a definite index of faecal contamination (ICMSF, 1982) and reflect the bad hygienic measures during the products production.

Recorded results in Table 2 revealed that, $54.3 \%$ of raw milk yoghurt samples recovered $E$. coli with highest frequency distribution of $17.1 \%$ and laid within the range of $3-<10 \mathrm{cfu} / \mathrm{g}$ and also within the range of $\geq 10^{3} \mathrm{cfu} / \mathrm{g}$ (Table 3). Lower results (19.04, 47.6, 22 and 40\%) were recorded by Ahmed and El-Bassiony (1978); Aboul-Khier et al. (1985); El-Bessery (2001) and Al-Hawary et al. (2005), respectively. However, higher result was revealed by El-Malt et al. (2013) where the authors recorded that 30 samples out of 50 samples had E. coli. Concerning pasteurized milk yoghurt samples, E. coli was recovered in percent of $2.9 \%$ (Table 2) and with frequency distribution of $2.9 \%$ and laid in the range of $10-<10^{2} \mathrm{cfu} / \mathrm{g}$ (Table 3). Higher result (12\%) was recorded by El-Malt et al. (2013). It worth to reveal that, 54.3 and $2.9 \%$ of raw and pasteurized milk yoghurt samples, respectively, failed to statutory with the Egyptian Standards limits due to presence of $E$. coli (Table 4). The high counts of coliforms, faecal coliforms and $E$. coli in the examined samples may be due to heavy contamination of these products from different sources. Moreover, the prevailing climatic condition in Upper Egypt in summer months, as well as, lack other facilities which encourage the growth and multiplication of existing organisms. Furthermore, E. coli frequently contaminate food and it is a good indicator of faecal pollution and its presence in milk products indicates presence of other Enteropathogenic microorganisms which constitute a public health hazard.

Anaerobes could not be detected in this study either in raw milk yoghurt or pasteurized milk yoghurt samples (Table 1). This result coincided with ElBessery (2001); Ali et al. (2004); Abdel-Aal (2008) and Sayed (2012). The failure in anaerobes detection in this study could be attributed to low $\mathrm{pH}$ and presence of lactic acids which may hamper anaerobes growth or due to other factors which need further investigations.

\section{CONCLUSION}

This study declared that, there are higher incidences of Enterococci, yeasts and molds, coliforms, faecal coliforms and E. coli in raw milk yoghurt than pasteurized milk yoghurt and there are high significance differences in yeasts \& molds counts between raw and pasteurized milk yoghurt and higher significance differences in coliforms presence between the two types of yoghurt. This study showed the availability of $E$. coli in the yoghurt which can be of health concern to consumers. The high level of coliforms, Enterococci, yeast and molds indicated neglected sanitary measures applied during production, handling, storage and distribution of yoghurt. Therefore, application of good hygienic measures during production, storage and distribution of such products are essential to improve yoghurt quality, consequently prevent the risk of human hazard. Likewise, rapid development of lactic acid by good starter culture and use of clean milk are essential for making the product unfavorable for growth and survival of these organisms.

\section{REFERENCES}

A.O.A.C. "Association of Official Analytical Chemists" (2000): Official Methods of Analysis. $17^{\text {th }}$ ed., Washington DC, USA.

Abdel-Aal, S.F. (2008): Microbiological research on some dairy products. Assiut Vet. Med. J., 54 (119): 54-68.

Aboul-Khier, F.A.; El-Bassiony, T. and Gad El-Rab, H. (1985): Enterobacteriaceae in some milk products in Sohag city. Assiut Vet. Med. J., 14 (28): 80-85.

Ahmed, A.A. and El-Bassiony, T.A. (1978): Microbiological evaluation of yoghurt 
produced in Assiut city. Assiut Vet. Med. J., 5 (9\&10): 168-177.

Al-Hawary, I.I.; Aman, I.M. and El-Kasas, W.M. (2005): Microbiological studies on fermented milks in Kafr El-Sheikh governorate. Alex. J. Vet. Sci., 23 (1): 1-11.

Ali, M.M.; Wahba, Nahed, M. and Farrag, Seham, A. (2004): Microbiological evaluation of Assiut market yoghurt through the shelf life time in refrigerator. Assiut Vet. Med. J., 50 (101): 64-77.

Cruickshank, R.; Duguid, J.P.; Marmion, B.P. and Swain, R.H. (1969): Medical Microbiology. $11^{\text {th }}$ ed., E. and S. Livingstone Limited Edinburgh and London.

Dardashti, A.D.; Afshin, A.; Saeed, B.; Grce, M.; Pigac, J. and Mrsa, V. (2001): Study of coliform, yeast and mold contamination of yoghurt in Ghaemshahr in Iran. Periodicum Biologorum, 103: 183-186.

Deibel, R.H. and Hartman, P.A. (1982): The Enterococci. In: Compendium of Methods for the Microbiological Examination of Foods. Speck, M.L. (Ed.), $2^{\text {nd }}$ ed., APHA., Inc.

E.O.S.Q.C. (2005): Egyptian Organization for Standardization and Quality Control. Egyptian Standards (E.S.): "Domiati cheese 1008-3/ Kareish cheese1008-4/ Ice cream 1185-1/ Yoghurt 1633".

El-Bessery, M.M. (2001): Microbiological quality of market fermented milks in Assiut city. M.V.Sc. Thesis, Fac. Vet. Med., Assiut Univ., Egypt.

El-Diasty, Eman, M. and El-Kaseh, R.M. (2007): Microbiological studies on raw milk and yoghurt in El-Beida City. Rese. J. Anim. Vet. Sci., 2: 34-38.

El-Malt, Laila, M.; Abdel Hameed, Karima, G. and Mohammed, A.S. (2013): Microbiological evaluation of yoghurt products in Qena city, Egypt. Vet. World, 6(7): 400-404. doi:10.5455/vetworld.2013.400-404.

Estrada, Z.A.; Mendoza, S.M.; La Garza, M.L. and Ferado, J. (1999): Behavior of enterotoxigenic strains of Staphylococcus aureus in milk fermented with yoghurt starter culture. Rev. Latinoam Microbiol., 41 (1): 5-10.

FAO "Food and Agriculture Organization" (1992): Manual of Food Quality Control. 4. Rev. 1. Microbiological analysis. Food and Agriculture Organization of the United Nations, Rome, Italy.

Harrigan, W.F. and MeCance, M.E. (1976): Laboratory Methods in Food: Dairy Microbiology. Academic Press London, New York, San Francisco.

ICMSF (International Committee on Microbiological Specifications for Foods) (1982): Microorganisms in Food. Vol. 1. Their significance and methods of enumeration. $2^{\text {nd }}$ ed., Univ. Toronto Press, Toronto, Buffalo, London.

Isam, A.M.; Eshraga, A.E.; Abu-Elgasim, A.Y and Efadil, E.B. (2011): Physicochemical, microbiological and sensory characteristics of yoghurt produced from camel milk during storage. Electronic J. Envi. Agricult. Food Chemistry, 10 (6): 2305-2313.

McKinley, M.C. (2005): The nutrition and health benefits of yogurt. Int. J. Dairy Technol., 58: $1-12$.

Oyeleke, S.B. (2009): Microbial assessment of some commercially prepared yoghurt retailed in Minna, Niger State. Afr. J. Microbiol. Res., 3(5): 245-248. Available online http://www.academicjournals.org/ajmr

Pazakova, J.; Turek, P. and Laciakova, A. (1997): The survival of Staphylococcus aureus during the fermentation and storage of yoghurt. J. Appl. Microbiol., 82: 659-662.

Penna, A.B.; Subbarao, G. and Barbosa-Cánovas, G.V. (2007): High hydrostatic pressure processing on microstructure of probiotic lowfat yogurt. Food Res. Int., 40: 510-519.

Rahimi, E. (2013): Enterotoxigenicity of Staphylococcus aureus isolated from traditional and commercial dairy products marketed in Iran. Brazilian J. Microbiol., 44 (2): 393-399.

Rao, C.U.; Shankar, P.A. and Laxminaryana, $H$. (1986): A study of Enterococci occurring in milk and milk products. Indian J. Dairy Sci., 39: 281-285.

Rodriguez, A.C.; Pintor, D.M.; Gonzalez, P.A.; Alvarez, M.R. and Hardisson, D.A. (1990): Microorganisms of Food hygiene interest in commercial yoghurts in the Canary islands. Alimentaria, 212: 55-58.

Ross, R.P.; Morgan, S. and Hill, C. (2002): Preservation and fermentation: Past, present and future. Int. J. Food Microbiol., 92: 3-16.

Roushdy, I.M.; Ehramann, M.A. and Vogel, R.F. (1998): Molecular identification and characterization of halo-tolerant lactic acid bacteria isolated from soft pickled Domietti cheese. Advances Food Sci., 20: 40-45.

S.P.S.S. "Statistical Package for Social Sciences" (2007): SPSS, version 16, Inc., Chicago, IL).

Salinas, R.J. (1986): Hygiene quality of commercial yoghurts. Alimentaria, 178: 27-30.

Sasidharan, S.; Prema, B. and Yoga, L. (2011): Antimicrobial drug resistance of Staphylococcus aureus in dairy products. Asian Pacific J. Tropical Biomedicine, (2011) 130-132. Journal homepage: Elsevier.com/ locate/apjtb

Saudi, A.M.; El-Essawy, H.A. and Hafez, N.M. (1989): Aspects on the microbiological quality of yoghurt plastic containers. Vet. Med. J. Giza, 37(3): 397-406. 
Sayed, M. (2012): Laban rayeb and yoghurt, rheology, chemical and microbiological properties. Assiut Vet. Med. J., 58 (132): 114-139.

Sinigaglia, M.; Gardini, F.; Lanciotti, R. and Massa, S. (1997): Mozzarella cheese: Monitoring of the productive life cycle and shelf-life evaluation. Advances Food Sci., 19: 54-58.

Sireli, T.U. and Ozdemir, H. (1998): Microbiological quality of fruit yoghurt marketed in Ankara. J. Vet. Med. Ankara Univ., 45(2-3): 287-293.
Tamine, A.Y. and Robinson, K. (2004): Yoghurt Science and Technology. Published by Institute of Applied Science, pp: 32-56.

Tamine, A.Y. and Robinson, R.K. (2007): Yoghurt: Science and Technology. $3^{\text {rd }}$ ed. Cambridge, Woodhead Publishing Limited.

Yasen, Nesma, I.S.; Abdel-Aal, S.F.; Mansour, M.A. and Amer, I.H. (2011): Evaluation of hygienic quality of large scale manufactured yoghurt sold in Sharkia governorate. Assiut Vet. Med. J., 57 (129): 58-77.

\section{المقارنة بين الحالة الميكروبيولوجية للزبادي المصنع من اللبن الخام و المبستر \\ أنسي أديب صادق ، منال محمد مبين ، محمود فرغلي حسبن \\ Email: Mahmoudfarghaly 1970@yahoo.com.}

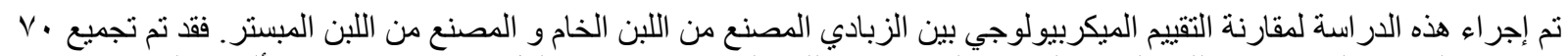

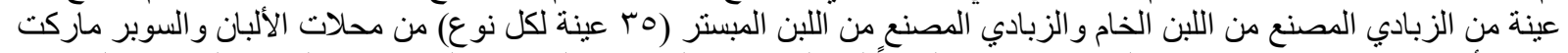

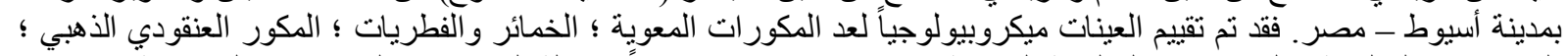

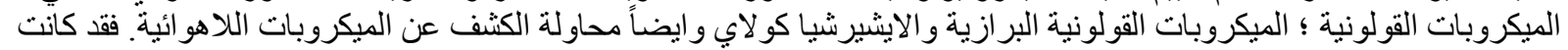

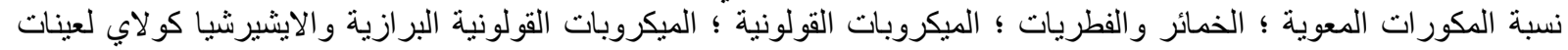

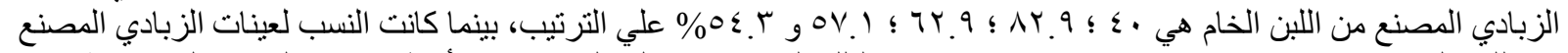

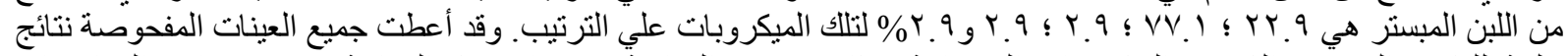

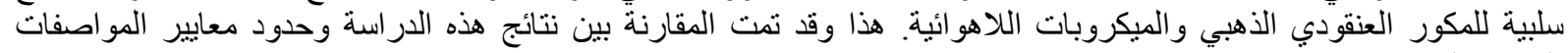

